\title{
MULTICENTRIC ORIGIN OF A RODENT ULCER 529
}

\section{MULTICENTRIC ORIGIN OF A RODENT ULCER.}

By Sir G. LENTHAL CHEATle, London.

Tre main object of this article is to direct particular attention to the remarkable changes in the basal layers of the epidermis and hair follicles which occurred in the skin round a rodent ulcer. The skin was described by Mr. Perey Legg as being infiltrated and not nodular.

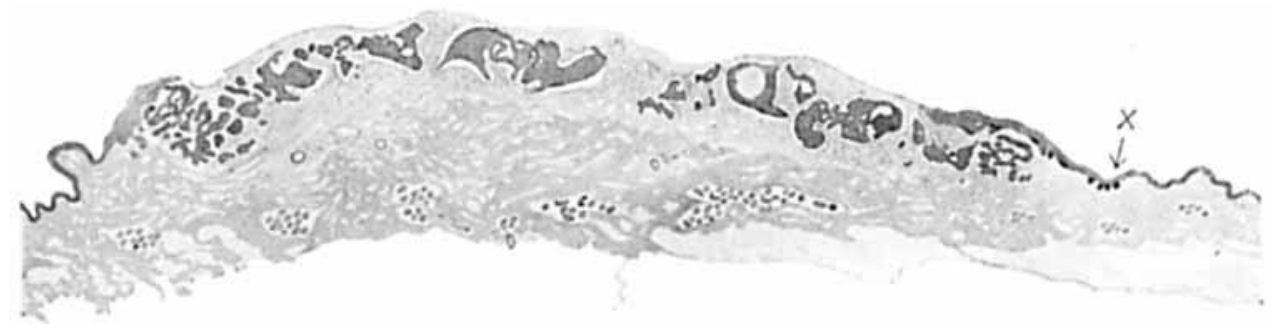

Fig. 518.-.-1 birdsery view of the rolent uleer. jight or nine deepjy-stained and isolated groups of eells are seen in the basal layer of the epidermis on the right of the ulert. $\mathrm{x}$ indicates the portion shown in Fig. $518 \mathrm{~d}$.

Fig. 518 A. ... Tw of tle wroups are seen under th higher nower, and are dipping into subjacent dermis, in which there are siens of chronic inflammation.
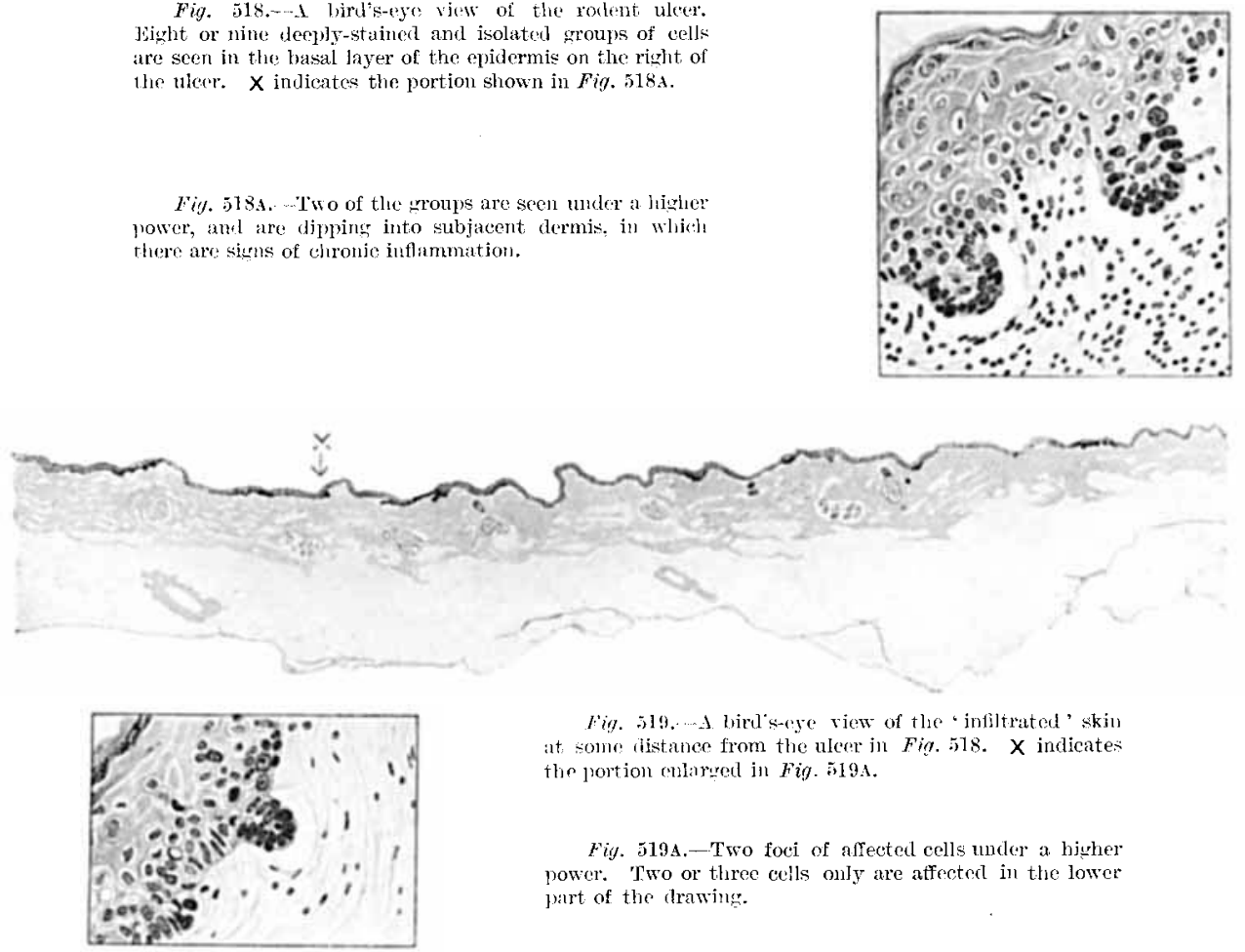

Fig. 519, I bird'seye view of the 'infiltruted'skin at come distance from the uleer in Fig. 518. $X$ indicates the portion colarged in Fig. $519 \Lambda$.

Fig. 519A.-Two foci of affected cells under a higher power. 'Two or three cells only are affected in the lower part of the drawintr.

I must make it perfectly clear that these changes occurred in separated, isolated patches which were not in continuity with the rodent ulcer or with each other, and they were not pigmented. 
Figs. 518 and 519 are bird's-eye views of the rodent ulcer and 'infiltrated' skin respectively. In these figures many darkly-stained, isolated, and small patches of cells are seen in the basal layer of epithelium; these are situated near the rodent ulcer in Fig. 518, and at some distance from it in the 'infiltrated' skin in Fig. 519. Fig. 521, B shows the same appearances occurring in the basal layer of epithelium in a hair follicle.

Under a high power the following changes may be observed: The pathological process appears to be a gradual one and occurs only in the basal layer of the epidermis and some hair follicles. Two or three epithelial cells stain more deeply than their neigh-

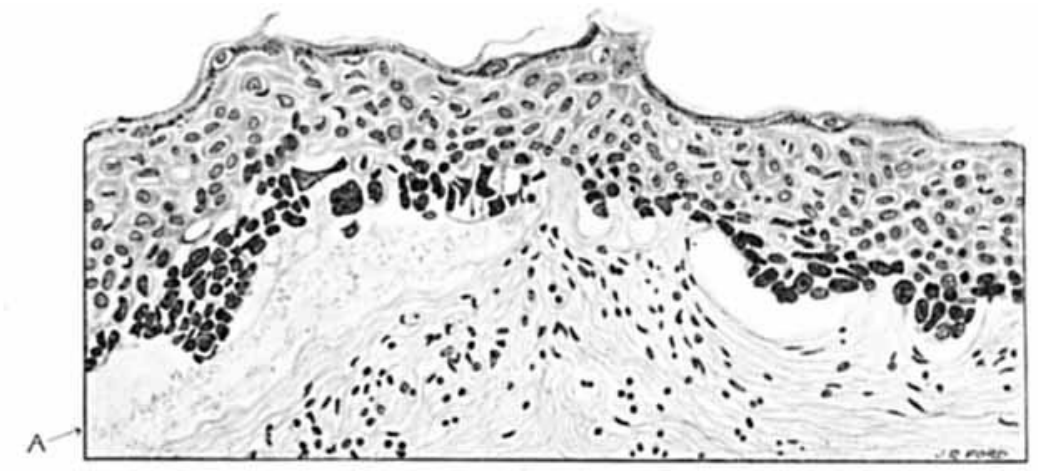

Fig. 520.--A Jarger area of affected basal cells. Their multiplication is marked. Theg are surroundon by coargated fluid (A) in the seetion.

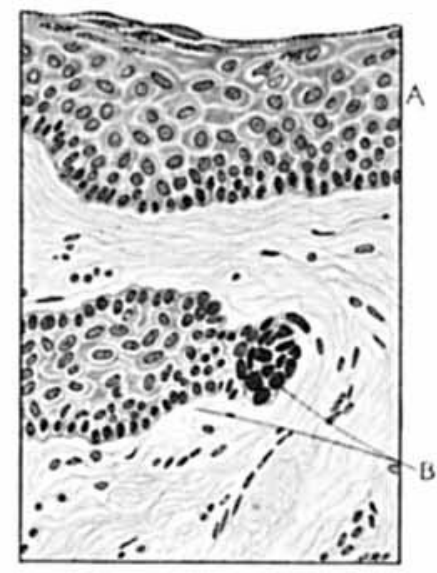

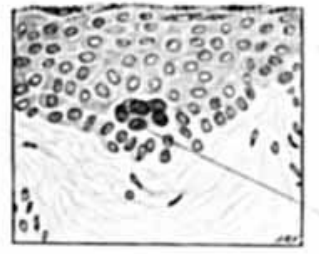

Fig. 522.- Shows a group of alien cells at $A$ above the basal layer in the epidermis taken one inch away from the edge of another rodent ulcer.

Fia. 521.-The affected colls indicated by the urper line at $B$ are in the basal laycr of a hair follicie. A, Epidermis.

bours, and are irregular in size and shape in the smallest lesions. (See Fig. 519A.) A further stage exhibits eight or ten cells of the same appearances, but in addition they have multiplied, and penetrated into deeper structures. (See Figs. 518A and 519A, and the hair follicle in Fig. 521, B.)

A still more extensive area is seen affected in Fig. 520, where some fifty or sixty cells are implicated, and their greater multiplication has resulted in a more definite invasion of deeper parts. Invasion is occurring in a branched and forked manner in other parts. There is chronic inflammation surrounding many of the spots where the epithelial changes 


\section{MULTICENTRIC ORIGIN OF A RODENT ULCER 531}

have taken place, and it is noticeable that coagulated fluid is encircling every point of epithelial change. (Fig. 520, A.)

These remarkable appearances in the skin round the rodent ulcer suggest a multicentric origin of this disease.

The tissues above described were removed by Mr. Percy Legg from the chest of an clderly unmarried female who was under the care of Dr. Arthur Whitfield. I thank them for their permission to refer to these tissues, and they are not responsible for the observations I have made.

The result of the examination of the skin surrounding the rodent ulcer of Dr. Whitfield's patient induced me to examine the skin surrounding other rodent ulcers.

Fig. 522 is a reproduction of the epidermis taken one inch from the edge of a rodent ulcer; a small group of cells can be seen at A, above the basal layer; they are larger, more irregular in shape, and more dceply stained than the normal cells around them. They are not pigmented. It is impossible to say how long they had been in that state and position.

Origin of Rodent Ulcers.- There is some confusion in the minds of authors as to whether rodent ulcers originate in the basal layer of epidermis, hair follicles, sebaceous fluids, or sweat glands. The changes seen in the rodent ulcer of Figs. 518 and 519 indicate that their genesis is in the epithelial cells in the basal layer of epidermis and in the basal layer of hair follicles. 